\title{
Chapter 13 \\ Path-Dependent Development of Mass Housing in Moscow, Russia
}

\author{
Maria Gunko, Polina Bogacheva, Andrey Medvedev \\ and Ilya Kashnitsky
}

\begin{abstract}
Since the 1950s, Moscow's housing development has been underlined by modernist planning schemes. From the 20th to 21 st centuries, the quality and appearance of apartment buildings changed, but housing estates designed as coherent neighbourhoods not only remain the principal type of housing organization but are still being constructed in Moscow and its suburbs. Though the concept itself has not been challenged by policy-makers and planners, by the end of the 20th century it became apparent that early housing estates have become a problem due to poor quality of construction. In 2017, the Moscow Government announced a highly controversial program suggesting the demolition of housing estates built between the 1950s and 1960s. Our contribution analyzes the history of housing estates development in Moscow aiming to understand what has led to the adoption of the 2017 "renovation" program. If this program ends up being fully implemented, along with planned renovation of former industrial areas, the cityscape of Russia's capital will be completely redefined.
\end{abstract}

Keywords Mass housing $\cdot$ Housing estates $\cdot$ Moscow, Russia Post-socialist city

M. Gunko $(\bowtie) \cdot$ A. Medvedev

Institute of Geography, Russian Academy of Sciences, Moscow, Russia

e-mail: msgunko@igras.ru
A. Medvedev
e-mail: medvedev@igras.ru
P. Bogacheva
Glorax Development, Moscow, Russia
e-mail: pb-gann@yandex.ru
I. Kashnitsky
National Research University Higher School of Economics, Moscow, Russia
e-mail: ikashnitsky@hse.ru
(C) The Author(s) 2018
D. B. Hess et al. (eds.), Housing Estates in Europe, The Urban Book Series, https://doi.org/10.1007/978-3-319-92813-5_13 


\subsection{Introduction}

A housing supply deficit was a persistent problem in Moscow throughout the 20th century caused by the accelerated rate of city's development. Between 1900s and 1910s the municipal government put much efforts into solving the issue, but lack of planning made the efforts insufficient (Brumfield 2002). The Russian Revolution of 1917 changed all aspects of social life in the country. In August 1918, the decree "On the abolition of private ownership of urban real estate" launched nationalization of housing stock. The first phases of Soviet housing policy, which were mostly about violent redistribution of nationalized properties and "squeezing" (the forced addition of residents to apartments), did not improve average residential conditions. The shortage of housing was further aggravated by a massive and intensified in-migration linked to industrialization (Denissenko and Stepanova 2013). Therefore, there was a strong necessity for cheap and extensive construction of new residential quarters. Meeting the above necessity, large housing estates (zhylye massivy) - uniformly developed housing areas consisting of mid-rise or high-rise apartment building (Metspalu and Hess 2018) and evenly distributed public services and facilities - i.e. outpatient clinics, kindergartens, schools, culture centers - have been constructed in Moscow since the end of 1950s. In Moscow, they are not interventions to the cityscape, rather they form the cityscape outside the historical city center. Moscow's housing estates, especially those constructed in the late Soviet period, tend to be massive in scale. In appearance, they resemble social housing in the countries of the Global North, which was intended for lower social status groups requiring assistance from the state. The difference lies in the Soviet ideology, which extended those principles to the entire population (Vysokovsky 2002).

Even today, new housing estates of various sizes are still being constructed in Moscow and its suburbs. Accounting for a greater part of housing stock in the city, they are not contested as a concept by policy-makers and planners, nor stigmatized in public discourses. However, early housing estates, consisting of so-called khrushchëvki apartment buildings (named after Nikita Khrushchëv during whose reign they were developed), are negatively perceived by many Muscovites. Since the end of the 1990s there have been both large-scale programs aimed at demolition of khrushchëvki neighborhoods, as well as individual reconstructions of apartment buildings based on private investments (Pogorelsky 2017). A highly controversial program announced in the beginning of 2017 suggested the entire demolition of khrushchëvki, replacing them with new housing estates which are to consist of high-rise apartment buildings (Moslenta 2017). In June 2017, Moscow city government approved the demolition of more than 4,000 apartment buildings in various location across the city. This hasty decision and the lack of clarity on implementation mechanisms brought thousands of Moscow residents into the streets in protest (Korzhova 2017). Our contribution analyzes the development of housing estates in Moscow aiming to understand what led to the adoption of the 2017 "renovation" program. If this program ends up being fully implemented along with 
a plan to renovate former industrial areas (Moscow City Hall 2017a), the cityscape of Russia's capital will be completely redefined.

A general limitation of our research is the scarceness of data on population characteristics which is a widely acknowledged problem (Vishnevsky and Zakharov 2010). However, the abundance of large housing estates in Moscow makes the city an interesting case for research; although the dominant nature of this type of housing makes it difficult to judge if some of the urban processes are affected by housing estates per se.

The chapter is structured as follows. First, we provide an overview of mass housing evolution in Moscow during the 20th-21st centuries; second, drawing on available data, we describe the main processes of social change within the city's districts; third, we discuss programs and individual interventions aimed at the alteration of khrushchëvki housing estates; in conclusion, we present an overview of the issues at hand.

\subsection{Evolution of Mass Housing in Moscow During the 20th and 21st Centuries}

During the 20th and 21st centuries, Moscow in its official boundaries increased from $176 \mathrm{~km}^{2}$ in 1915 to $2,519 \mathrm{~km}^{2}$ in 2015 (Fig. 13.1). The population size has correspondingly increased from 1.8 million people to 12 million (Denissenko and Stepanova 2013). Such an expansion has led to a substantial transformation of its built environment and housing development.

There were several waves of mass housing construction in Moscow, different in volume and type of constructed housing, as well as ideology, underlying architecture and urban planning.

The first wave of Soviet housing construction (1920s to mid 1930s) was the era of avant-garde style in architecture, when projects revolutionary in construction and design were proposed and widely implemented. Residential construction was mainly conducted through standalone projects: communal houses and residential complexes of a transitional type, where partial or complete collectivization of everyday life would be possible. Apart from the ideology, it was believed that communal houses helped to save on the cost of living due to collective use of an auxiliary area (Bliznakova 2002). Those houses were built mainly as a comfortable accommodation for non-families, students, and the like (Khan-Magomedov 2007).

The second wave of Soviet construction (mid 1930s to mid 1950) is known as the Stalinist period, which saw a shift towards a distinctly retrospectivist architecture (Paperny 2016). The new style emerged in 1932 with a design contest for the Palace of Soviety, which was never constructed in the end. After this contest, all major projects were proposed in the new Stalinist style, while projects in avant-garde style were no longer approved for construction (Khmelnitsky 2006). The new housing, so-called stalinki, were massive four- to nine-storied apartment 


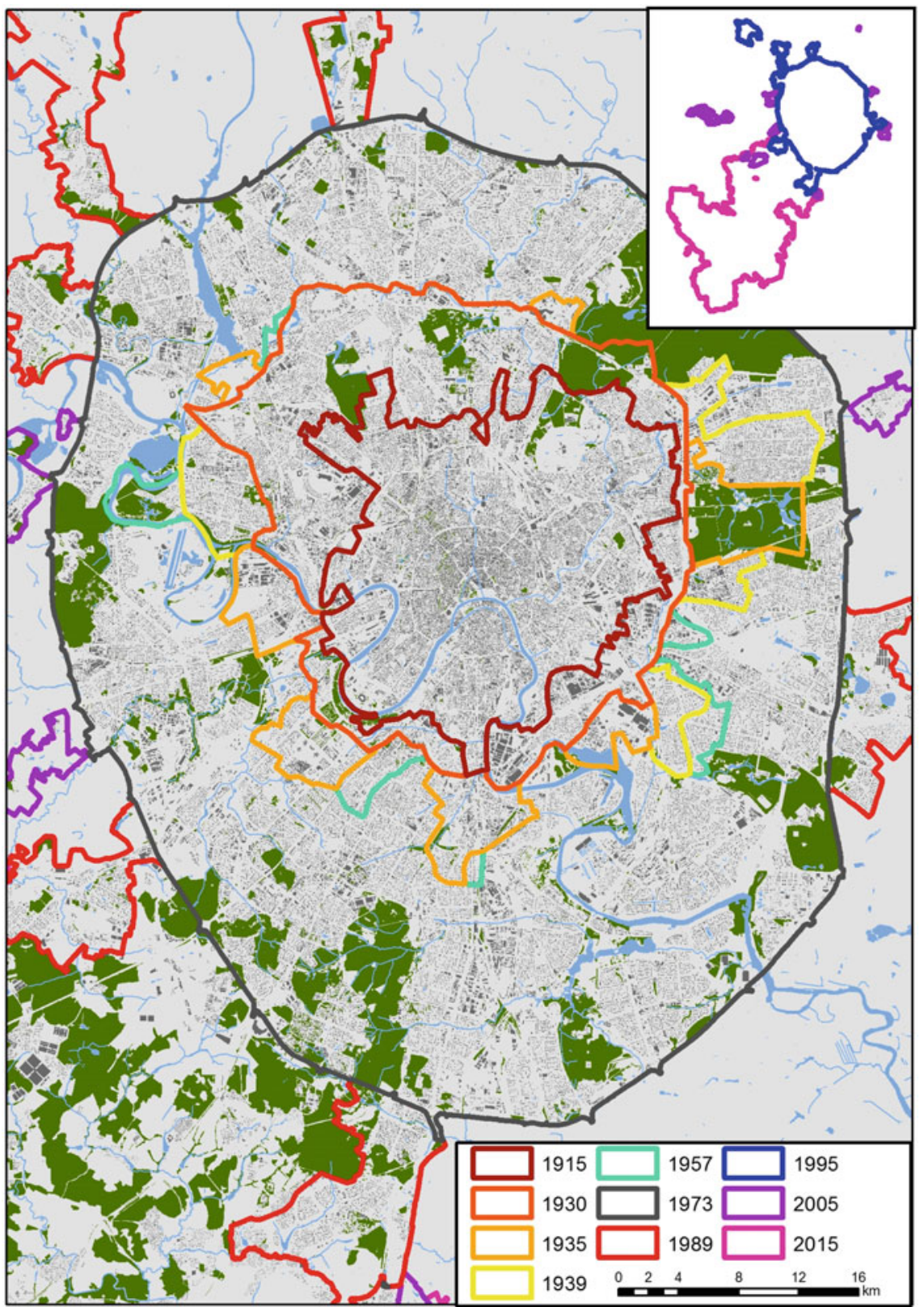

Fig. 13.1 Moscow's official boundaries in the 20th-21st centuries. Figure prepared by: Andrey Medvedev. Source Alferov 1939; Central Intelligence Agency 1957; Katalog geodannikh 2005; Khorkov 1935; Mesheryakov 1930; Portal otkritikh dannykh 2015; Sultanova 1973; Suvorin 1915; Ustav goroda Moskvi 1995; Zaytseva 1989 
buildings with spacious apartments, high ceilings, and rich personal facilities. To build them, some of the old city quarters were demolished in 1932-1934. Stalinki were mainly constructed as individual projects for the upper strata of the Soviet society and were located in prestigious locations of the city. Apart from elite apartment buildings, nine simplified types of stalinki were developed, most of which can be found in Moscow. They consisted of less comfortable housing intended for working class people. Built in small numbers, they were usually located near factories or at the city's outskirts and other neighborhoods with underdeveloped infrastructure. Those simple stalinki formed the first, small- scale housing estates in the city, though it was just the beginning of the housing estates era in Moscow.

The third wave of Soviet construction (mid 1950s to late 1960s). The reign of Nikita Khrushchëv started with a partial reflection on the faults of Stalin's epoch. The resolution "On the elimination of excesses in designing and construction" in 1955 was a notable part of de-Stalinization. Urban planning principles, which had been utilized for a quarter of a century, did not anticipate the development of a city as a system of large residential areas with appropriate infrastructure. Therefore, the basic principles of new, modernist, urban planning were adopted from the West (Khmelnitsky 2017). During the following five to seven years, professional guidelines in urban planning and architecture in the Soviet Union changed significantly, including the norms of providing citizens with housing and social care, the scale of funding for civil construction, principles of organization of the urban environment, typology of housing and residential infrastructure, and official architectural style. The organization of new residential areas closely followed the core principles of Clarence Perry's Neighbourhood Unite Scheme (Perry 1929): main streets with shops were placed along the perimeter of residential areas, with schools and kindergartens in their center surrounded by apartment buildings and green spaces with playgrounds and sports fields.

The khrushchëv period saw a complete transition to housing estates as the main type of mass housing organization in Moscow (and other cities of the Soviet Union), intended for all citizens. This differed fundamentally from Stalin's Moscow, which consisted of a ceremonial center with elite housing for privileged populations and quarters of barrack-like buildings where working class people lived. Newly built housing estates consisted of mid-rise (four- or five-storied) apartment buildings, constructed from panels of large blocks, designed for 80-100 apartments (about 300 inhabitants). Over ten type series of khrushchëvki apartment buildings were developed between the 1950s and 1960s (Fig. 13.2).

Construction of khrushchëvki was aimed to solve the housing shortage problem as quickly as possible, which manifested itself in the low quality of the buildings. The comfort of apartments was traded for speed of construction (Proekty domov 2017). They had low ceilings, extremely small rooms, thin walls, and poor soundproofing. On the other hand, even these low-quality apartments were a huge step forward compared to the previous housing of their new inhabitants.

The first and canonical khrushchëvki housing estates - the Ninth quarter of Novie Cheremushki district in the south-west of Moscow_was planned in 1955- 


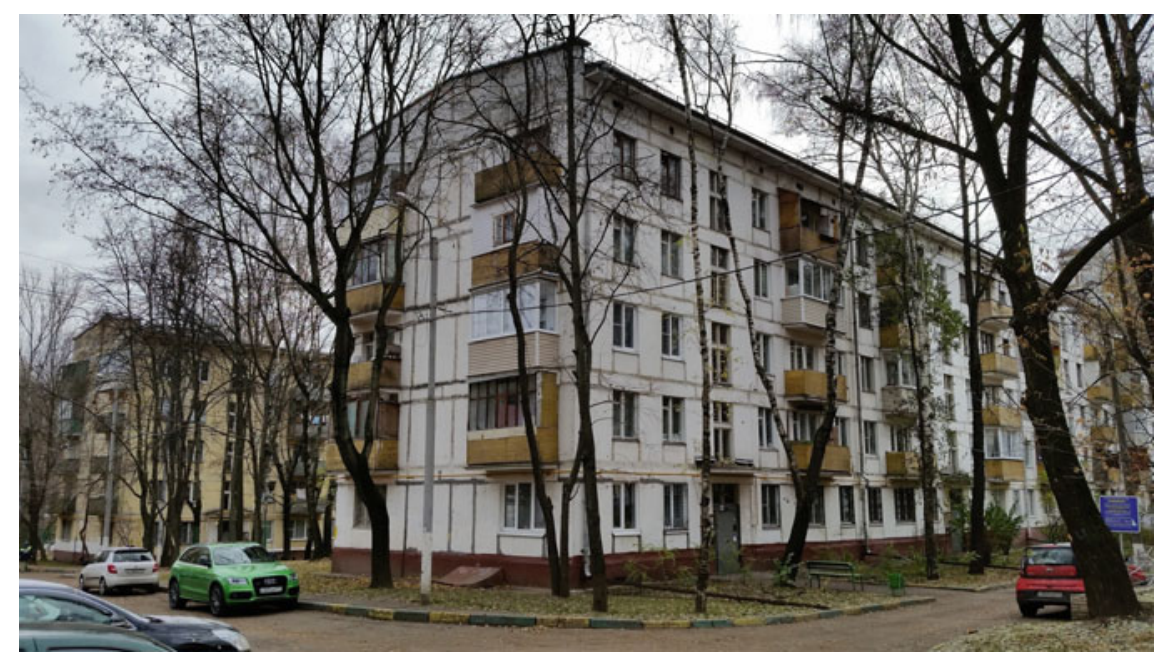

Fig. 13.2 Khrushchëvki apartment building in Nagorny district, southern administrative okrug of Moscow. Source Igor Sokolov

1956 (chief architect Natan Ostermann). The project was already implemented in 1958. This first housing estate became the prototype of all residential areas built in the Soviet Union in coming decades. The name Cheremushki itself became a metaphor signifying a generalized standard of a housing estate with a developed system of public services and monotonous five-storied large-block or large-panel apartment buildings (Ikonnikov 1984).

The fourth wave of Soviet construction (late 1960s to late 1980s). Housing estates consisting of khrushchëvki had for the most part solved the problem of housing shortage in Moscow, although, demand for better quality housing together with nonstop in-migration required continuous territorial expansion of the city. Starting from the late 1960s, housing estates consisted of eight- or nine-storied apartment buildings; later the average number of storeys increased to 12 and to 17 (Fig. 13.3).

Moreover, some of those housing estates constructed in the late 1950s were supplemented by high-rise apartment buildings which somewhat contributed to a revival of those areas, mitigating their monotony. Since this construction started during the reign of Leonid Brezhnev, these high-rise apartment buildings were called brezhnevki, although this term is not widely used because there are at least 40 main housing type series (Proekty domov 2017). Apartments in brezhnevki were more spacious and comfortable compared to those in khrushchëvki. Depending on the type series, each apartment building consists of over 400 apartments (circa 1000 inhabitants). The most common among them are $\Pi-44$ buildings (Fig. 13.4). Around 1200 such apartment buildings were constructed in Moscow's peripheral districts between the 1980s and beginning of 2000 s. 


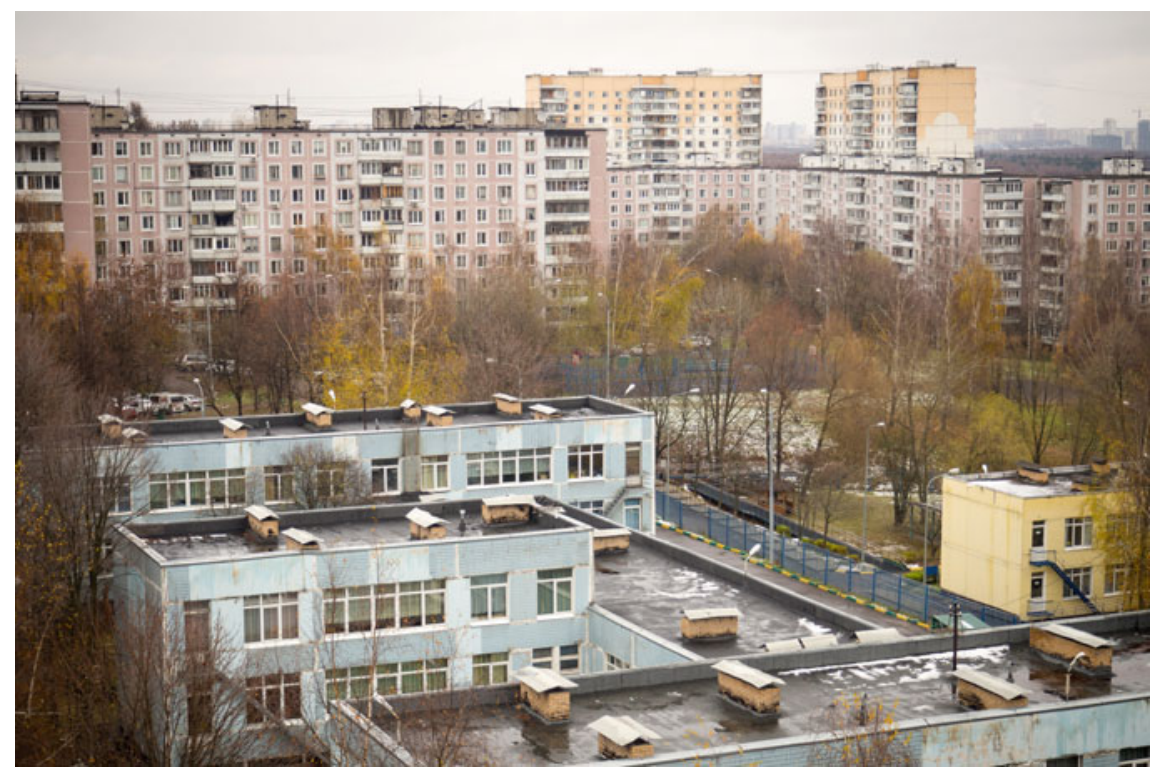

Fig. 13.3 Typical configuration of Soviet neighborhood constructed in 1970s, including a playground, sports field (blue structure behind trees), school (yellow two-storey building) and kindergarten (blue two-storey building) in Yasenevo district, southern administrative okrug of Moscow. Source Inna Zyuganova

Generally, there were two ways to obtain housing in a newly built apartment building in Moscow, and the Soviet Union in general: to lease it from the state (or employer) or to buy a cooperative apartment. However, cooperative apartments, which were distributed among members only, accounted for no more than $8 \%$ of newly constructed housing in Moscow (Kommersant 2010). Public housing was constructed by and belonged to institutions and municipalities. Institutional housing was allocated to workers of enterprises and organizations, as well as some categories of people defined in legislation (e.g. Heroes of the Soviet Union, women with the medal "Mother-heroine", distinguished workers of arts and sciences). The regulations to receive housing from institutions and municipalities were almost identical, except that queues for municipal housing were longer.

The Soviet housing program in Moscow appeared to be successful if you looked at the enormous volume of construction that met an unprecedented housing demand. On the down side, the quality of apartment buildings and the infrastructure in newly constructed quarters were low. For the communist party, the success of the housing program was measured by one key indicator - the number of new square meters constructed. All other important matters like the comfort of the apartments or the aesthetics of living environment were ignored (Ruble 2002; Vysokovsky 2002). Such a quantitative focus resulted in a dull monotony of housing and urban environment in general. Moreover, the choice of accommodation was extremely 


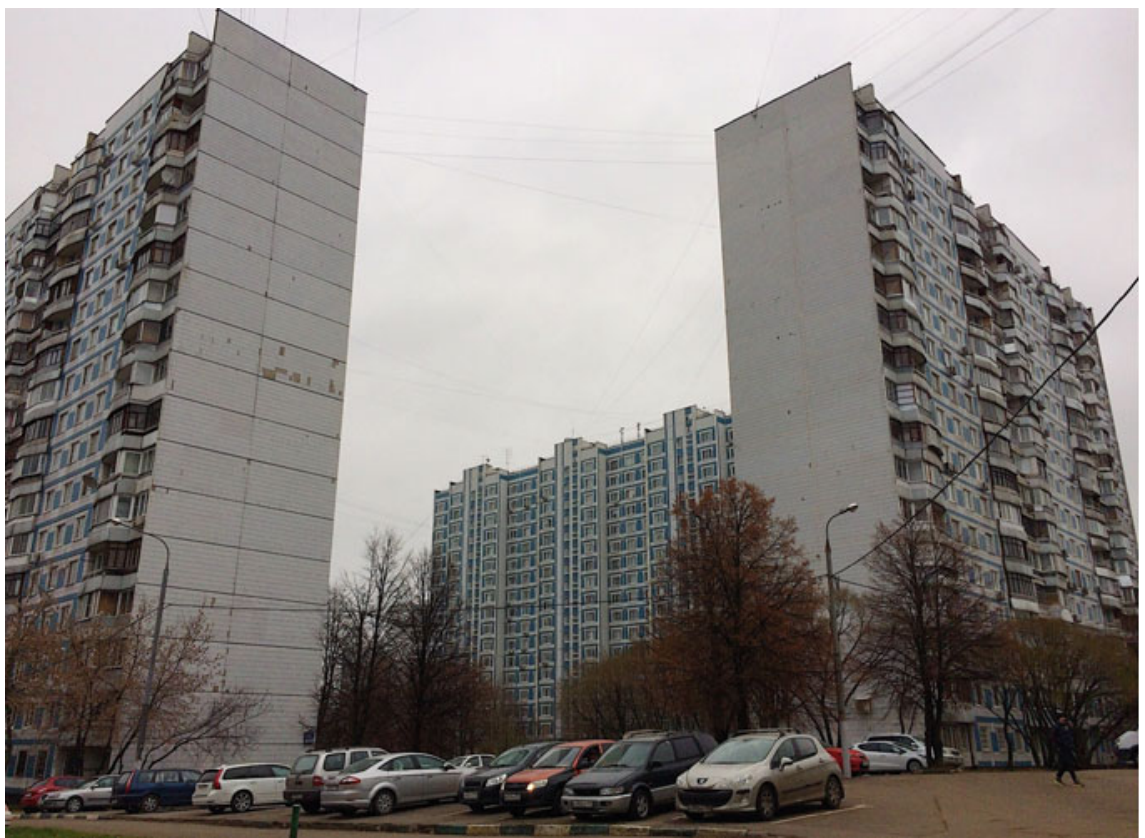

Fig. 13.4 Late Soviet housing estate (constructed in mid-1980s) with П-44 apartment buildings, Orekhovo-Borisovo Uzhnoe district, southern administrative okrug of Moscow. Source Maria Gunko

limited. Housing, just like any other product distributed in the form of rations, was typical, average, and mostly low quality (Khmelnitsky 2017).

Post-Soviet period of construction. One of the main changes in the post-Soviet era was the recognition of private property rights, giving birth to a housing market which resulted in new massive interventions to Moscow's built environment. Mass privatization of housing was officially allowed in Russia on 4 July 1991 when the law "On privatization of housing fund in the Russian Federation" (Russian Government 1991) was adopted. According to the document, housing could be privatized free of charge if there was consent of all residents, timely payment of housing and communal services, and fulfillment of several other conditions depending on the type of housing. No associations were formed to manage apartment buildings. Privatization was individual and voluntary and, if desired, residents could continue living in their apartments without privatizing them on terms of social hiring. At the present time, there are still around $10 \%$ of apartments in Moscow which are not privatized (TASS 2016).

In the early stages of the real estate market, the main property buyers were new businessmen. They preferred elite housing constructed in prestigious locations that usually had big apartments, private parking, and security. Even though this new type of construction was very prominent, the actual share of such buildings in the overall structure of post-Soviet housing stock remains quite moderate. 
Most new housing in the 1990s was panel housing estate built by order of Moscow's city government, which had enormous social responsibilities. New districts were located outside the MKAD, Moscow's Ring Road which circles the city and delineates the "traditional" territory of Moscow, or in previously industrial peripheral areas. More than half of new apartments were allocated to citizens eligible for social housing improvement programs, the remaining were sold freely by the city government itself. By the end of the 2000s, social and commercial housing resembling housing estates in greenfields was finally being squeezed out of the Moscow Ring Road to territory further afield. An exception was the district Kurkino, which is a rare case of a carefully designed neighborhood for 10 thousand inhabitants built of high-quality low-rise houses resembling those in European cities. The apartments here were sold to middle class people, and none of them were allocated via social programs (Postanovlenie Pravitelstva Moskvy 1994).

The global financial crisis of 2008-2009 coupled with a change in the management team of Moscow Government in 2010 naturally affected the development of the city. The issuance of new permits for construction was suspended, while most previously agreed contracts were terminated. As a result, the pace of mass housing construction reduced trifold by 2012; initiation of new projects became very rare. Among other, to boost the stagnating housing market, in 2012, the territory of Moscow was expanded 2.5 times. But even five years later, the New Moscow remains an underdeveloped peripheral area where relatively cheap panel housing estates prevail (Fig. 13.5).

Figure 13.6 illustrates the spatial distribution of housing estates in Moscow. Their construction started at the boundaries of the historical city center, and gradually captured new areas. Currently, the first established mid-rise housing estates are located in the areas of "middle belt", while more recent high-rise housing estates dominate in semi-peripheral and peripheral districts.

\subsection{Socio-spatial Stratification of Moscow}

To better understand socio-spatial stratification of Moscow, one needs to consider long-lasting spatial patterns of housing prestige, which were formed in the 19th century and are still pronounced in the cityscape. There are two major gradients of housing prestige in Moscow: center-peripheral and sectoral (or West-East) (Popov 2014). Today, housing prestige is manifested in the symbolic advantage of the city center where historical and cultural institutions are located. The sectoral differentiation is almost as pronounced as center-peripheral; outside the city center it becomes the prime determinant. Further, we use the term "prestige vector" to designate the more prestigious districts that are located along the major radial highways. There are three such vectors: north-western, south-western and western.

Nationalization of housing in the Soviet Union and the following centralized distribution resulted in a deep social and residential interfusion, when people of different cultural, social, and financial levels began to live in the same apartment 


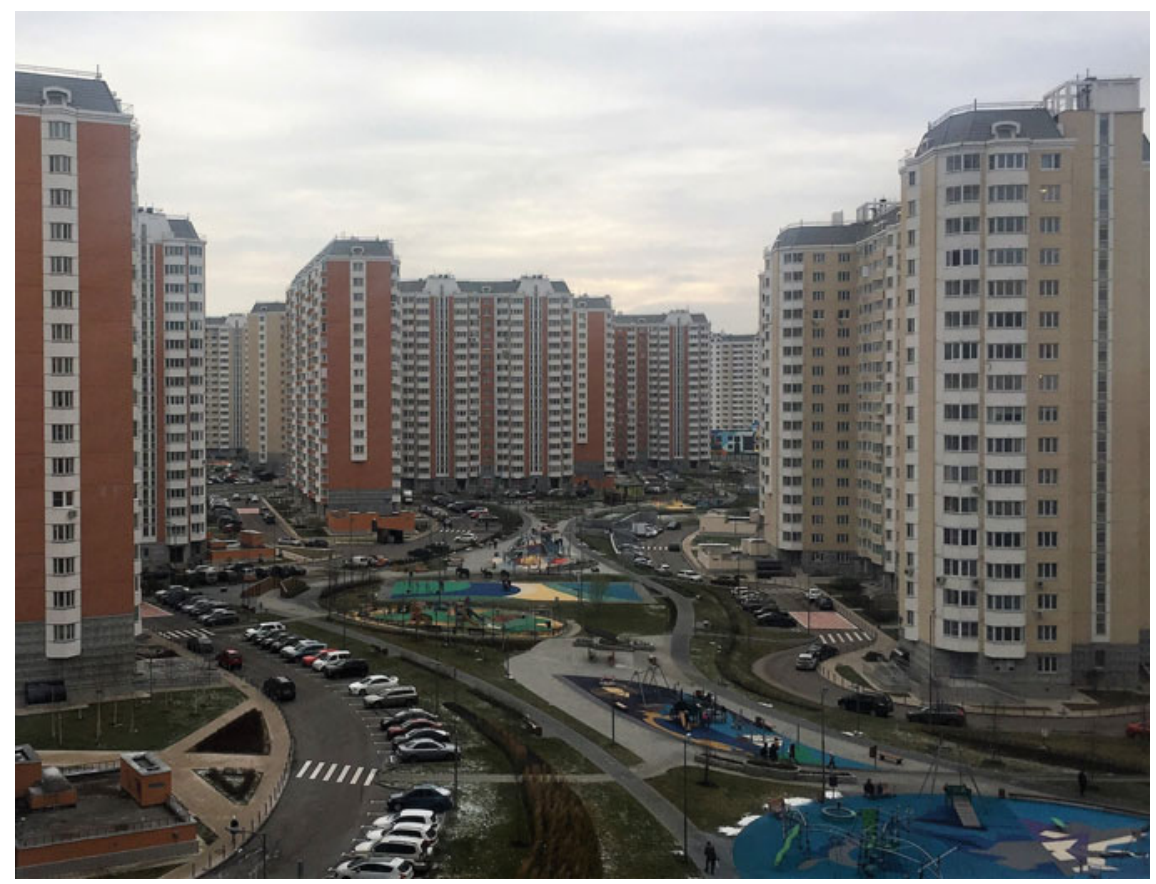

Fig. 13.5 Post-Soviet large housing estate in Vnukovskoe settlement, New Moscow. Source Maria Lazareva

buildings or neighborhoods. Nevertheless, even the new mixed reality was not uniform across the city. Social composition of housing estates was determined largely by the institution that received the property for its employees. People of working class lived mostly in the eastern, south-eastern and southern parts of the city in khrushchëvki and brezhnevki housing estates. Elites resided in the city center and the areas along the prestige vectors where unique elite apartment buildings and housing estates were constructed, forming the so called "golden ghettos". Social stratification existed but was based on occupation rather than income (Vendina 1997). In the post-Soviet period, the emergence of a free housing market, new commercial development, reorganization of industrial enterprises, and finally, increased in-migration and intra-urban mobility of the population were the factors that determined the evolution of socio-spatial stratification in Moscow (Popov 2007). As was noted in the introduction, a significant challenge for our research is the absence of official data on main population characteristics. Therefore, we use proxies based on available data to broadly describe the current patterns of Moscow's socio-spatial stratification at the level of city districts.

Stratification via property is studied using data on housing ownership because rental arrangements are largely undocumented. Furthermore, up to $85 \%$ of Moscow's residents are owners of their properties (Popov 2007). The evolution of property stratification is approximated via transactions in both primary and 


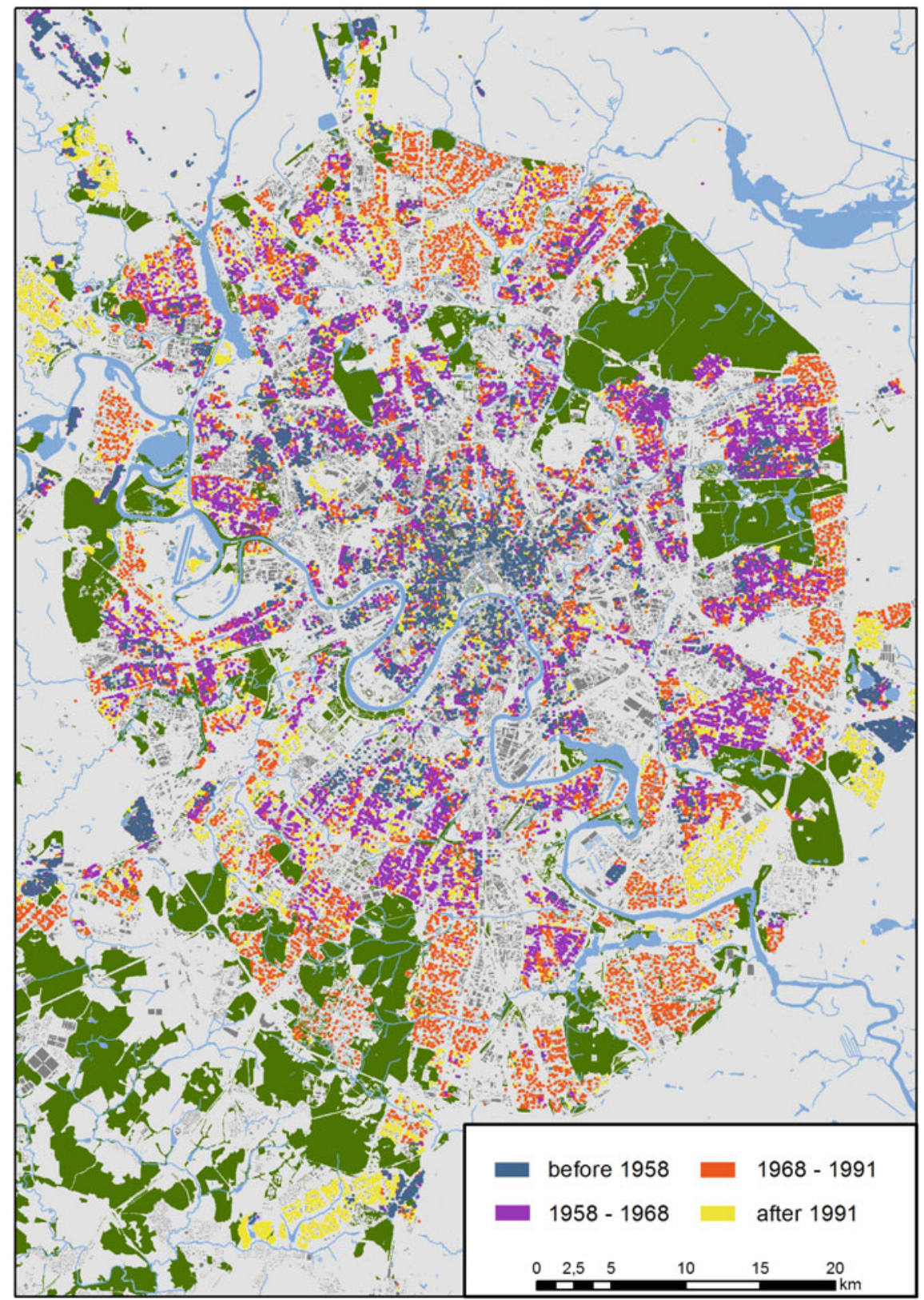

Fig. 13.6 Age of housing in Moscow; locations of housing estates can be delimited with a certain probability based on the dates of housing construction: 1958-1968 are khrushchëvki housing estates, 1969-1990 are brezhnevki housing estates, and after 1990 new housing estates are constructed in peripheral and semi-peripheral districts. Figure prepared by: Andrey Medvedev. Source BTI 2017 
secondary housing markets. At the level of city districts, the average prices for housing clearly show the south-western and north-western prestige vectors. Interestingly, the new elite of the 2000s have been choosing the same locations that were considered prestigious in the era of a planned economy. These areas have some objective advantages like transport infrastructure, amenities, and aesthetic living environment, i.e. proximity to the floodplain of the Moskva River. The property stratification derived from the housing transaction data shows much less stratification in the eastern districts compared with the western locations. Thus, this major spatial pattern indicates that even if there is gentrification (understood widely as "upgrading" of depressed areas) in peripheral and semi-peripheral districts, its pace is slow.

Car ownership per 1000 people in 2010 was highest in the areas of freshly built top-level housing. Thus, the level of motorization is mostly useful for identifying the new most prestigious residential areas.

Educational stratification. A lack of opportunity to freely change the place of residence in the Soviet era created a tendency of settlement near the places of employment, which formed clear boundaries between the zones with population of different educational level. The modern spatial pattern of educational stratification largely inherits patterns of the Soviet era. Higher levels of education were typical not only for the population of the city center, but also the districts located on the south-western and north-western vectors of prestige, where the scientific elite of Moscow State University and the institutes of the Academy of Sciences of the Soviet Union received housing. The belt of housing estates along the north-western vector of prestige was populated by scientific personnel of the aviation and space industries, as well as representatives of creative intelligentsia. The least educated population resided in the industrial east and south, as well as in the northern periphery. The emergence of the housing market launched a somewhat disruption in the spatial distribution of highly educated people. The areas of intensive commercial housing construction in the most recent decades usually attracted new residents of higher educational level, as buyers are mostly middle-class people (Popov, personal communication, 2017; Kuricheva, personal communication, 2017).

To delineate the areas of old and new prestige, we use data on spatial distribution of scientific staff. From the Soviet time, the popularity of a neighborhood among the scientific elite was closely associated with the overall prestige of a district. Even today only areas located along the south-western and north-western prestige vectors have relatively high proportions of residents with scientific degrees. One of the reasons why academic degrees give such a clear distinction lies in the fact that, while the acquisition of higher education in general became more widespread, getting an academic degree is still almost exclusively an endeavor for people of higher social strata.

Electoral pattern of stratification. Electoral geography of Moscow is well-covered in research (Kolosov and Borodulina 2004; Zhidkin 2002). We only focus on the most evident patterns in the way Moscow's population votes, since electoral preferences of the population indicate the dynamics of social movements within the city. For the purposes of interpretation, we divide the political spectrum 
into four broad types (communist, democratic, pro-Government, remainder), and conduct analysis for two periods: 1996-2005 and 2011-2013. There is a clear negative correlation $(-0.96)$ between the support of democrats and pro-Government politics. The support of democrats is higher in the areas of rapid social replacement, where younger and more educated people settle. The support of communists is concentrated in the old prestigious locations, where the academic elites and former nomenklatura reside. However, the areas of voting for democrats and communists intersect; the main distinction between them lies in the speed of social renewal.

Given the fairly stable electoral preferences of the main social groups, the dynamics of voting results can be used to assess changes in the social structure of districts. Central districts, where the process of gentrification is going on, are notorious for their support of democrats, while the leader of democratic voting is the new middle-class district Kurkino. Territories with mass housing construction in the first wave of post-Soviet development, as well as renovated districts, show tendencies towards democratization.

Findings. Various types of social stratification show quite similar spatial patterns giving the opportunity of using a composite index to map them (Fig. 13.7). The composite indicator is the average of five normalized indictors: average price of an apartment bought in the district, number of cars per 1000 people, number of inhabitants with tertiary education per 1000 people, number of inhabitants with an academic degree per 1000 people, share of votes for democrats.

Some transformations of social structures happen uniformly, while others contribute to polarization of the social cityscape. The key role in the process of stratification is played by re-distribution and replacement of population via intra-urban mobility and in-migration. In such an attractive city for migrants as Moscow, it is logical to assume that characteristics of migrants determine the dynamics of the neighborhoods' social structure. The contribution of migration in shaping social structure at the level of city districts was researched in detail previously (Kashnitsky and Gunko 2016) based on migration data for 2012, and no update of this data was published since. Generally, the level of ethnic and social segregation of migrants in Moscow is quite low (Demintseva 2017; Kashnitsky and Gunko 2016). Migrants are able to settle in virtually any districts of the city due to the rich variation of their residential strategies (Demintseva 2017).

The rate of social structure renewal is approximated in the current research by activity in the real estate market. We evaluated the activity of the primary market through the volume and qualitative characteristics of the newly constructed housing stock, and the secondary housing market, through the number of registered housing purchase transactions. The coefficient of social renewal is the arithmetic mean of the normalized renewal ratio of the housing stock and housing transactions. We interpret this composite index as the rate of physical change in the composition of population.

We observe higher levels of the composite index in the following groups of districts (Fig. 13.8). First, central districts, where the share of new housing stock is quite moderate, but the quality of the older apartment buildings is often high. Usually these districts experience top levels of activity at the secondary real estate 


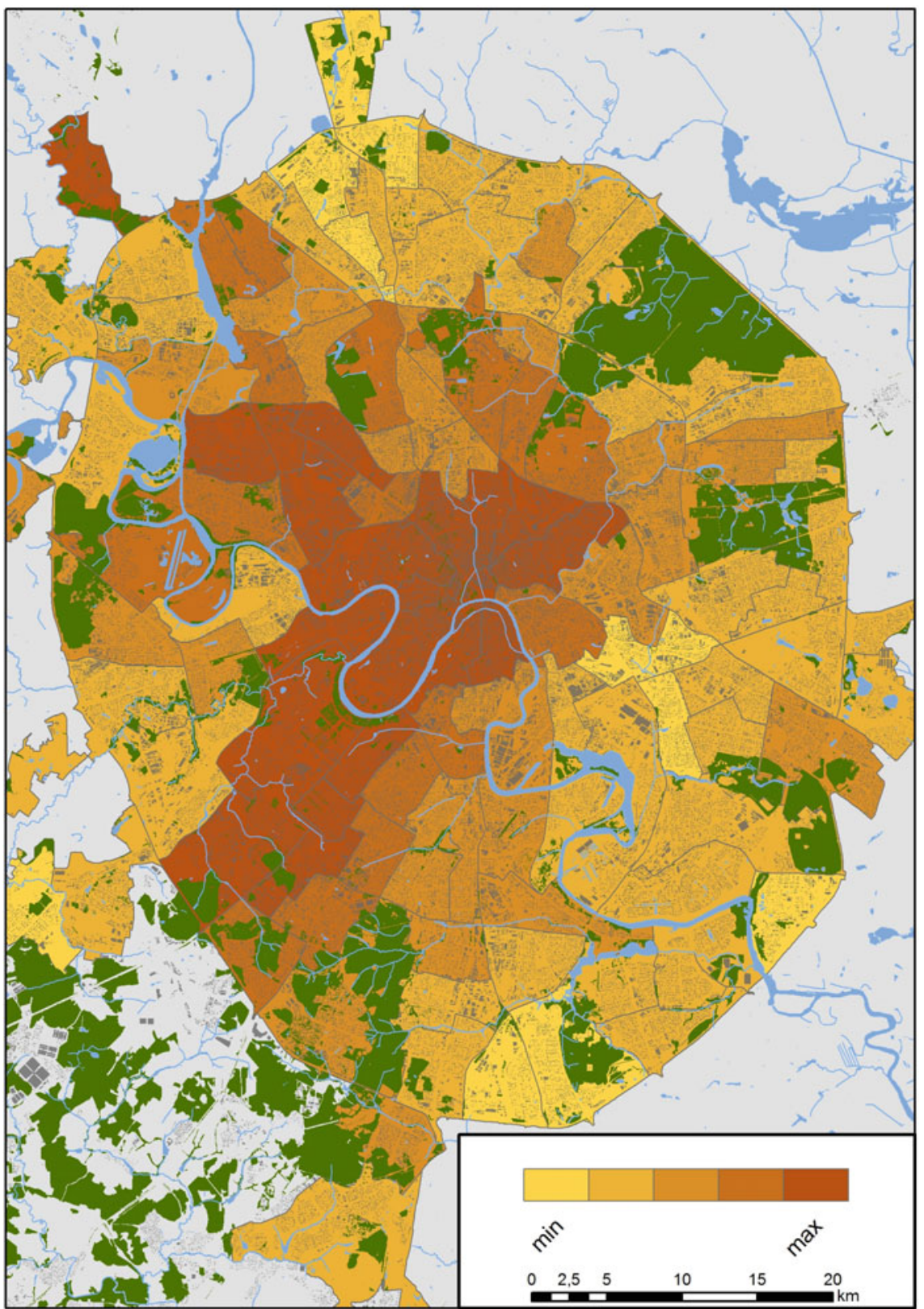

Fig. 13.7 Composite of Moscow's socio-spatial stratification; higher values indicate higher average social status of residents. Figure prepared by: Andrey Medvedev. Source BTI 2017; Department of Territorial Agencies of Executive Power 2012; Rosreestr 2014; Rosstat 2010; TsiK 2014 


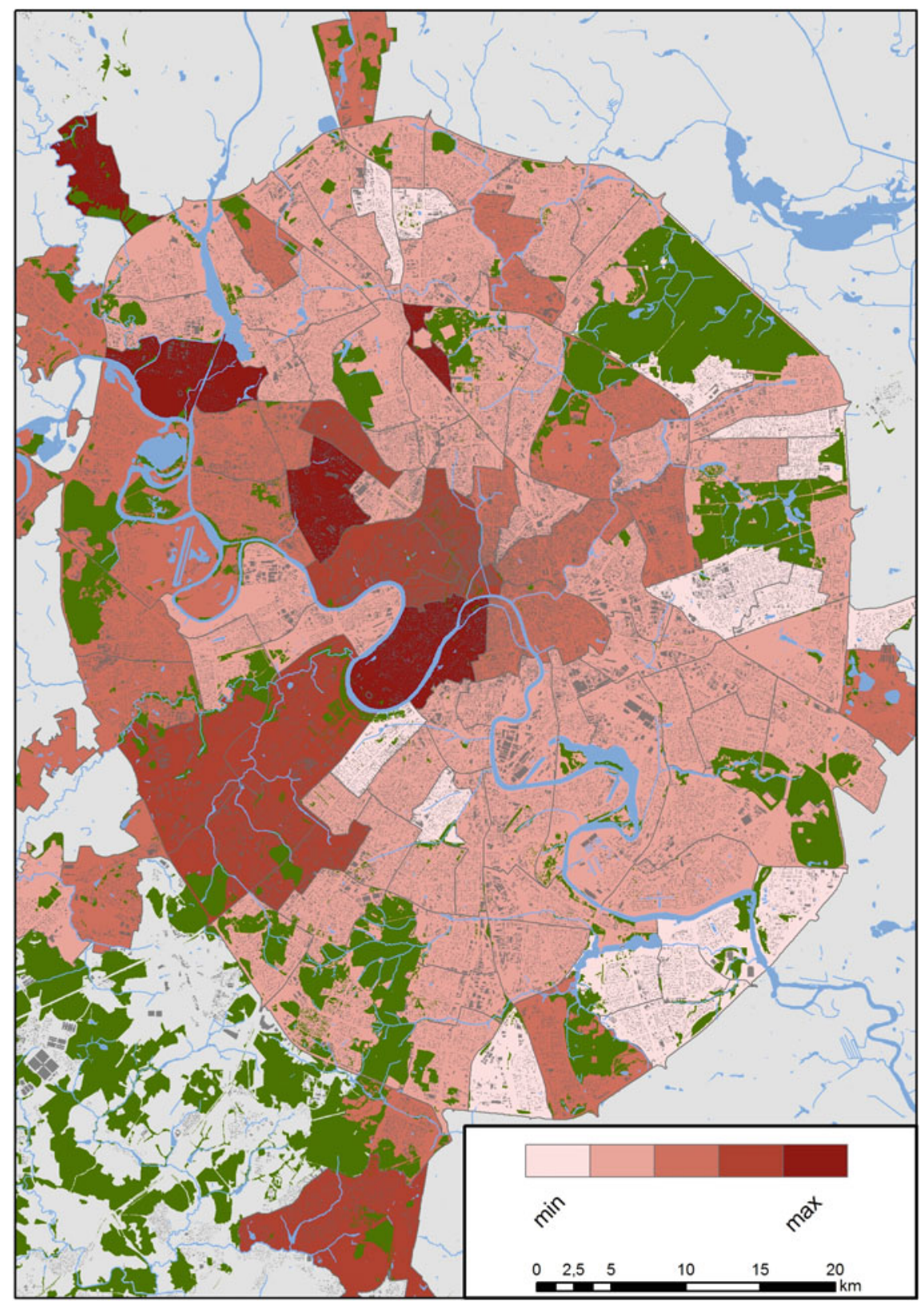

Fig. 13.8 Spatial patterns of the social renewal coefficient. Figure prepared by: Andrey Medvedev. Source BTI 2017; Rosreestr 2014 
market, suggesting an ongoing gentrification. Second, districts along the vectors of prestige with stalinki as the main housing, supplemented by post-Soviet individual elite apartment buildings and housing estates. Third, significantly renovated districts. Two subtypes can be distinguished here: reorganized industrial areas and districts along the vectors of prestige where the first program of khrushchëvki estates demolition was implemented. Fourth, peripheral areas that were developed in the 1990s and early 2000s.

In contrast, low rate of social renewal is characteristic of almost the whole periphery of non-prestigious sectors built up in the late Soviet period with large panel housing estates, particularly southern and south-eastern districts.

Overall, by the beginning of the 2010 s, the social structure of the city was self-reproducing preserving most of the Soviet patterns of socio-spatial stratification. Interestingly, new construction of cheap mass housing does not lead to deterioration of the social structure, but rather improves it. The reason is the general inflated cost of housing in Moscow. As a result, buyers of commercial new buildings, even in the most inexpensive segment, are young, civically-active, educated people with relatively high and stable income (Popov, personal communication, 2017). Furthermore, new housing now is designed to include room at the ground floor for shops, cafes, and other services that are in high demand by local business, which, in turn, positively affects the quality of life in such areas. Therefore, newly developed areas, even those being built up with relatively low-budget housing estates are, in many respects, the centers of positive change on the periphery.

\subsection{Demolition, Reconstruction and "Renovation" of Khrushchëvki Housing Estates}

Built in the1950s and 1960s, khrushchëvki apartment buildings were subject to a complete overhaul 50 years later. However, by the end of the 1980s many buildings were already in derelict condition (Department of Urban Development Policy 2017). In 1988, four apartment buildings were dismantled in Novie Cheremushki district, although demolition did not become widespread. The first organized resettlement took place in 1993 after mass complaints of Fili-Davydkovo district residents who pointed to the unbearable living conditions in khrushchëvki apartment buildings. The cost of neighborhood reconstruction was not included in the city budget so a private investor became involved in the project. After technical examination showed reconstruction to be impossible, a seventeen-storied apartment building was constructed for the resettlement of khrushchëvki residents (Department of Urban Development Policy 2017). 
In 1999, Moscow Government started a program "Comprehensive reconstruction of the areas of five-storied apartment buildings ${ }^{1}$ built during the first period of industrial housing construction" (Moscow Government 1999) which was aimed at demolishing old apartment buildings and replacing them with new ones simultaneously enhancing the built environment, e.g. constructing new playgrounds and recreational spaces. It was intended to demolish apartment buildings according to the type series, thus covering entire housing estates; however, the approach was to evaluate buildings on an individual basis. The program contained strict criteria and reasons for demolition. In order for each particular building to be subjected to demolition, it had to undergo a thorough technical examination to determine its condition and inhabitability. In total 12 million $\mathrm{m}^{2}$ (out of 20 million) of housing have been demolished in the course of the program (Pertsova 2017). The majority of demolished khrushchëvki housing estates were located in the Central, Southern, South-Eastern and Northern administrative Okrugs of Moscow. By the beginning of 2017, around seventy apartment buildings entitled to demolition within the framework of this first phase remained in Moscow (Department of Urban Development Policy 2017).

To relocate residents, new housing was built in the same district by private investors, who had signed a contract with Moscow Government. The excess of apartments was sold freely on the market. Owners of apartments in the apartment buildings entitled to demolition could refuse relocation options proposed by the Moscow Government and require alternatives. Also, there was an opportunity to move into a larger apartment (including one located in another district) by paying for the extra square meters at a market price. Generally, in districts along prestige vectors, elite housing was constructed in place of demolished khrushchëvki. In other districts, replacement housing comprised typical post-Soviet panel housing estates.

Alongside mass demolition, there were individual projects of khrushchëvki renovation and reconstruction based on private initiative and investments. Apartment buildings were not only overhauled, including improvement of water and electrical supply systems, energy efficiency, and soundproofing, but often increased by two or three floors. Residents of such reconstructed buildings did not pay the investors. Investors made their profit from the sales of new apartments located at the overbuilt floors (Pogorelsky 2017).

Today, the remained khrushchëvki are colloquially sometimes called khrushchëby, a combination of words khrushchëvki and trushcheby (slums in Russian) although, with the mixed social landscape within residential neighborhoods and separate apartment buildings remaining from the Soviet times, none of

\footnotetext{
${ }^{1}$ The program was primarily focused at khrushchevki, i.e. mass demolition have undergone khrushchevki type series K-7, II-32, II-35, 1МГ-300, 1605-AM and their modifications; however, other five-storied apartment buildings could have been demolished as well, if they fit the criteria for demolition.
} 
the city districts have become places of true ethnic segregation or socio-economic disparity (Demintseva 2017; Vendina 2004). In February 2017, the question of five-storied housing stock renovation was raised again by the current mayor, Sergey Sobyanin (Moscow City Hall 2017a). Although, there are a number of successful examples of reconstruction of five-storied apartment buildings in other post-socialist cities, as well as in Moscow itself, Moscow Government is campaigning in favor of mass demolition (Pogorelsky 2017; Russian Agency for Legal and Judicial Information 2017). A fundamental difference of the new "renovation" program from the one launched in 1999 is that now it is not only apartment buildings in dire condition that are subject to demolition and resettlement (Pertsova 2017). The initially named volume of the project was 7934 apartment buildings which would result in the resettlement of around 1.6 million people (Bekbulatova et al. 2017). Later, the list of buildings to be included in the program was reviewed. In early May 2017, Moscow Government published a preliminary list of 4566 apartment buildings located in 85 districts. Formal criteria were: date of construction between 1957 and 1968, use of standard construction material and techniques, and maximum height of 5 storeys. In addition to krushchëvki, the list included about 100 buildings which were late stalinki, avant-garde apartment buildings, and pre-revolutionary housing. During one month from 15 May until 15 June 2017, a vote was taken among apartment owners and tenants (if the apartment was not privatized) for the inclusion of apartment buildings from the preliminary list into the program. They could cast their vote through online applications or at meetings of property owners. For the building to be included in the program, two thirds of apartment owners and tenants had to vote for the inclusion. After voting the program included 4087 apartment buildings (Moscow City Hall 2017b). The preliminary list did not include nine-storied panel housing; however, Sergey Sobyanin noted that the city government will consider the possibility of their demolition with the consent of residents, if those apartment buildings are in poor condition and fall within the quarters chosen for the demolitions (Stulov 2017). By August 2017, the renovation program included 5144 apartment buildings (Moscow City Hall 2017c).

So far, it is not immediately clear what will be constructed instead of the demolished housing. Moscow Government announced plans to hold an international architectural contest for the development of new neighborhoods which will be erected at five experimental sites in the city (Vedomosti 2017). According to Sergey Sobyanin, the number of storeys in new apartment buildings will be up to twenty, individually determined for each neighborhood (Moslenta 2017). The new program has been criticized by many experts and civic activists (e.g. Zubarevich 2017), and its proposal led to mass street protests at the end of spring 2017. There is a widespread perception that Moscow Government lacks money and resources to implement the program (Liyauv and Gruzinova 2017). 


\subsection{Conclusion}

The post-Soviet period saw a major but not yet uniform shift towards a better quality of living environment in Moscow. The majority of derelict apartment buildings were demolished, as well as estates of obsolete housing built in the 1950s and 1960s. Traditional panel construction was reviewed in 2015 when new standards of construction quality were adopted (Department of Urban Development Policy 2017). Implementation of "My Street", a project of the Moscow Government aimed at improving the aesthetics of the urban landscape, began in 2016. Within its framework, streets are being repaired and landscaped, while the facades of buildings are restored and lighted (Moscow City Hall 2017a). But despite all innovations and improvements, housing estates remain the principal type of housing organization. First constructed in the $1950 \mathrm{~s}$ to address the unprecedented housing need, they have undergone changes in appearance, but the original modernist planning scheme is still reproduced in newly developed residential quarters. The number of new housing estates within the traditional geographical territory of Moscow, delineated by the Moscow Ring Road, decreased, but apartment buildings within it grew in height. Developers prefer to construct multistoried complexes to maximize revenues as the usual area for construction is barely 5-7 hectares (Popov, personal communication 2017). In the New Moscow where available lands are still abundant, new housing comprises massive panel housing estates built in "green fields", while individual projects like the low-rise complex Kurkino are rather an exception.

Since the collapse of the Soviet Union, interventions to Moscow's housing estates from the city's Government and property owners have been primarily driven by the poor condition of apartment buildings. In 2017, the mass demolition of khrushchëvki housing estates proposed by the Moscow Government has become the main topic on the agenda of architects, planners, and civic society. The need to do something with the remaining khrushchëvki housing stock is recognized by most experts (Zaytseva and Kosareva 2017), but there is still no consensus on how to reconstruct the quarters (Butuzova 2017). Meanwhile, no interventions are being suggested to alter housing estates constructed in the late Soviet times where the quality of the apartment buildings is relatively high, compared to that of khrushchëvki. Those neigbourhoods, however, face other problems, among them poor quality of public spaces, lack of both high- and low-end commercial services and amenities, low aesthetic qualities of the living environment (Novikov, personal communication, 2017; Kuricheva, personal communication, 2017). Not being the object of a deliberate policy, positive changes in those neighborhoods, if any, are usually the result of coincidence rather than planned actions of the city Government (Popov, personal communication, 2017).

At the moment, it is difficult to say how the areas where mass demolition of khrushchëvki has been proposed will change, since the prospect of their redevelopment has not yet been presented to the public and discussed. One thing is certain - the concurrent demolition of khrushchëvki quarters and the gentrification of 
Moscow's old industrial zones may potentially bring long-awaited changes to the stagnated Moscow cityscape.

Acknowledgements The authors express deep gratitude to all experts who participated in interviews and to colleagues who helped with illustrative material. The research was supported by the Basic Research Program of the National Research University Higher School of Economics and Basic Research Program of the Institute of Geography, Russian Academy of Sciences (No. 01201352495 and No. 01201352481).

\section{List of interviewees}

Ekaterina DEMINTSEVA - director of the Centre for Qualitative Social Policy Research at the National Research University Higher School of Economics, Moscow. Interview held on 11 April 2017.

Yury KOCHETKOV - head of analytics and marketing department at the engineering and construction company IFK "Fort", Moscow. Interview held on 23 June 2017.

Ekaterina KURICHEVA - senior analyst at design bureau KB Strelka, Moscow. Interview held on 24 April 2017.

Alexey NOVIKOV - dean of the Vysokovsky Graduate School of Urbanism at the National Research University "Higher School of Economics", Moscow; president of Habidatum International, Inc., New York. Interview held on 19 May 2017.

Alexey POPOV - head of the Centre for Real Estate Data and Analytics (CIAN), Moscow. Interview held on 17 May 2017.

\section{References}

Alferov NV (1939) Plan Moskvi [General layout of Moscow]. Moscow

Bekbulatova T, Voronov A, Ivanov M (2017) Renovatsiya na marshe [Renovation on the march]. Kommersant. https://www.kommersant.ru/doc/3237430

Bliznakova M (2002) Sovetskoy zhilishnoe stroitelstvo v godi eksperimenta 1918-1933 [The Soviet housing construction in the years of experiment 1918-1933]. In: Brumfield WC, Ruble B (eds) Zhylitshe v Rossii XX vek. Tri kvadrata, Moscow, pp 53-89

Brumfield WC (2002) Stroitelstvo: komfort i pribil [Construction comfort and profit]. In: Brumfield WC, Ruble B (eds) Zhylitshe v Rossii XX vek. Tri kvadrata, Moscow, pp 35-52

BTI (2017) Database of Moscow housing. Moscow Bureau of Technical Inventory. http://www. mosgorbti.ru

Butuzova L (2017) Arkhitektor Krotov—o renovatsii: "Moskvichi rastvorytsya kak sakhar v chae" [Architect Krotov - about the renovation: "Muscovites will dissolve like sugar in tea"]. Novie Izvestiya. https://newizv.ru/interview/14-04-2017/arhitektor-krotov-o-renovatsii-moskvichirastvoryatsya-kak-sahar-v-chae

Central Intelligence Agency (1957) Guide to streets and locations in Moscow

Demintseva E (2017) Labour migrants in post-Soviet Moscow: patterns of settlement. J Ethnic Migrat Stud 43(15):2556-2572. https://doi.org/10.1080/1369183X.2017.1294053 
Denissenko MB, Stepanova AV (2013) Dinamika chislennosti naseleniya Moskvi za 140 let [Dynamics of Moscow population over 140 years]. Vestnik MSU. Economics 3:88-97.

Department of Territorial Agencies of Executive Power (2012) Programs of integrated development of Moscow's administrative districts 2012-2016. Moscow Government, Moscow. http://dtoiv.mos.ru/legislation/projectsotchets/detail/851969.html

Department of Urban Development Policy (2017) Kompleks gradostroitelnoy politiki [Housing policy roadmap]. Moscow Government. https://stroi.mos.ru/snos-piatietazhiek

Ikonnikov AV (1984) Arkhitektura Moskvi: XX vek [The architecture of Moscow: 20 century]. Moskovsky rabochy, Moscow

Kashnitsky I, Gunko M (2016) Spatial variation of in-migration to Moscow: testing the effect of housing market. Cities 59:30-39. https://doi.org/10.1016/j.cities.2016.05.025

Katalog geodannikh (2005) Catalogue of Moscow city geodata. Moscow committee on urban planning and architecture. http://egip.mka.mos.ru/egip/egip.nsf/va_GeoDataCatalogByCat? OpenView

Khan-Magomedov SO (2007) Ilya Golosov. Arkhitektura-S, Moscow

Khmelnitsky DS (2006) Arkhitektura Stalina: Psikhologiya i stil [Stalin's architecture: Psyhology and style]. Progress-Traditsiya, Moscow

Khmelnitsky DS (2017) Reformy Hrushheva. Chto sluchilos' s sovetskoj arhitekturoj v pjatidesjatye gody? [The reforms of Khruschëv. What happened to the Soviet architecture in the 1950s?]. Gefter. http://gefter.ru/archive/21563

Khorkov BF (1935) Skhema planirovki Moskvi [A planning scheme of Moscow]. Moskovsky rabochy, Moscow

Kolosov VA, Borodulina NA (2004) Elektoralnie predpochteniya izbirateley krupnikh gorodov Rossii: tipy i ustoychivost (1995-2003) [The electoral preferences of voters in large Russian cities: types and stability (1995-2003)]. Polis (Politicheskie Issledovaniya) 4:70-79

Kommersant (2010) Zhylyschnye kooperativy v SSSR [Housing cooperatives in the USSR]. https://www.kommersant.ru/doc/1495585

Korzhova D (2017) Protestujushhie protiv snosa pjatijetazhek v Moskve prinjali rezoljuciju [Protesters against the demolition of five-story buildings in Moscow adopted a resolution]. Vedomosti. https://www.vedomosti.ru/realty/articles/2017/05/14/689732-protestuyuschie-protivsnosa-pyatietazhek

Liyauv B, Gruzinova I (2017) Snos pyatietazhek kak predvybornaya programma Sobyanina. Snos pyatietazhek kak predvybornaya programma Sobyanina [Demolition of five-story buildings as a pre-election program Sobyanin]. Vedomosti. https://www.vedomosti.ru/politics/articles/ 2017/03/06/680010-snos-pyatietazhek-kak-predvibornaya-programma

Mesheryakov NL (1930) Moskva. Skhematichesky plan [Moscow. A schematic general layout], Sovetskaya entsiklopediya, Moscow

Metspalu, Hess DB (2018) Revisiting the role of architects in planning large-scale housing in the USSR: the birth of three large housing estates in Tallinn, Estonia. Plan Perspect 33(3):335-361. https://doi.org/10.1080/02665433.2017.1348974

Moscow City Hall (2017a) City's projects. https://www.mos.ru/city/projects/

Moscow City Hall (2017b) Itogi golosovaniya po proektu renovatsii [The voting results on the renovation project]. https://www.mos.ru/news/item/25633073/

Moscow City Hall (2017c) A map has been published showing houses that entered the renovation program of the house. https://www.mos.ru/news/item/27345073

Moscow Government (1999) Resolution of the Moscow Government. http://docs.cntd.ru/ document/901738444

Moslenta (2017) Renovatsionnyy opyt [Renovation experience]. https://moslenta.ru/govoryat/ francuzskiiopyt.htm

Paperny VZ (2016) Kultura dva [The second culture], 4th edn. Novoe literaturnoe obozrenie, Moscow

Perry C (1929) The neighborhood unit, a scheme of arrangement for the family-life community. Regional survey of New York and its environs, vol 7. Committee on the Regional Plan of New York and Its Environs, New York, pp 2-140 
Pertsova V (2017) Sobyanin i Luzhkov: kak razlichajutsya programmy ren-ovacii dvuh moskovskih mjerov [Sobyanin and Luzhkov: how different are the programs for the renovation of two Moscow mayors]. Forbes. http://www.forbes.ru/biznes/344649-sobyanin-iluzhkov-chem-otlichayutsya-programmy-renovacii-dvuh-moskovskih-merov

Pogorelsky A (2017) Nadstrojka 2.0. Kak zhiteli pjatijetazhek Moskvy ras-shirjajut svoi kvartiry [Add-on 2.0. How the inhabitants of 5-storeyed buildings enlarge their apartments]. RBK. https://realty.rbc.ru/news/598478429a79473d6b86ebbe

Popov AA (2007) Territorialnaya differentsiatsia kachestva gorodskoy sredy v Moskve [Spatial differentiation of urban environment quality in Moscow].Vestnik MSU. Geography 4:29-36

Popov AA (2014) Prostranstvenno-vremennoj analiz faktorov tsenoobra-zovaniya na rinke zhiloj nedvizhimosti [Spatiotemporal analysis of key factors for residential real estate estimates in Moscow]. Regionalnie issledavaniya 46(4):70-80

Portal otkritikh dannykh (2015) The open data portal of the Moscow Government. Moscow Government. https://data.mos.ru/

Postanovlenie Pravitelstva Moskvy (1994) Postanovlenie Pravitelstva Moskvi \# 471-ПП ot 7.06.1994 "O zastroyke zhilogo rayona Kurkino" [The Resolution of the Moscow Government № 471-ПП from 7.06.1994 "About the development of residential district "Kurkino"].

Proekty domov (2017) Proekty domov po periodam industrialnogo domodtroeniya [Specifications of houses by periods of industrial housing construction]. http://www.apb1.ru/proekty-domovpo-periodam-industrialnogo-domostroeniya.html

Rosreestr (2014) Database of Moscow's real estate. Russian Federal service for state registration, cadastre, and cartography in Moscow. https://portal.rosreestr.ru/wps/portal/p/is/cc_informSections/ ais_mrn

Rosstat (2010) Russian Census 2010. Population structure by municipalities. Federal State Statistics Service. http://www.gks.ru/free_doc/new_site/perepis2010/croc/perepis_itogi1612.htm

Ruble B (2002) Ot "khrosheb" k korobkam [From "khroshebi" to boxes]. In: Brumfield WC, Ruble B (eds) Zhylitshe v Rossii XX vek. Tri kvadrata, Moscow, pp 139-161

Russian Agency for Legal and Judicial Information (2017) Snos khrushchevok v Moskve: al'ternativnyye stsenarii [Demolition of Khrushchev in Moscow: alternative scenarios]. http:// www.rapsinews.ru/incident_publication/20170411/278158355.html

Russian Government (1991) Federalniy zakon ot 4.07.1991 \# 1541-1 "O privatizatsii zhilogo fonda v Rossii" [Federal law from 4.07.1991 \# 1541-1 "On the privatization of housing in Russia"]. http://www.consultant.ru/document/cons_doc_LAW_100/

Stulov M (2017). Pod snos v Moske mogut popast ne tolko khruchevki, no i devytaetazhki [Not only khruchevki may be demolished in Moscow, but also nine storey houses]. Vedomosti. https://www.vedomosti.ru/economics/articles/2017/03/06/680008-snos-moskve-hruschevkidevyatietazhki

Sultanova N (1973) Skhematichesky plan [Moscow. A schematic general layout]. Moskovsky rabochy, Moscow

Suvorin AS (1915) Plan goroda Moskvy s prigorodami [General layout of Moscow city with suburbs]. Novoe vremiya, Moscow

TASS (2016) Privatizatsiya zhil'ya v Rossii [Privatization of housing in Russia]. http://tass.ru/ info/3426534

TsiK (2014) Database of the Russian central election commission. Russian central election commission. http://www.vybory.izbirkom.ru/region/izbirkom

Ustav goroda Moskvi (1995) Zakon goroda Moskvi ot 28.06.1995 [Law of Moscow city from 28.06.1995]

Vedomosti (2017) Vlasti Moskvy provedut arkhitekturnyy konkurs po programme renovatsii zhil'ya [The Moscow authorities will hold an architectural competition for the program of housing renovation]. https://www.vedomosti.ru/realty/news/2017/04/25/687305-arhitekturniikonkurs-programme-renovatsii

Vendina OI (1997) Transformation processes in Moscow and intra-urban stratification of population. GeoJournal 42(4):349-363. https://doi.org/10.1023/A:1006890108182 
Vendina OI (2004) Moskva etnicheskaya: grozit li gorodu getoizaciya? [Ethnic Moscow: will the city turn into a ghetto?]. Demoscope Weekly 177-178. http://demoscope.ru/weekly/2004/ 0177/tema01.php

Vishnevsky AG, Zakharov SV (2010) Chto znaet i chego ne znaet ros-siyskaya demograficheskaya statistika [What Russian demographic statistics does and does not know]. Voprosi Statistiki $2: 7-17$

Vysokovsky AA (2002) Ujut-ne-geroy [Comfort is not a hero]. In: Brumfield WC, Ruble B (eds) Zhylitshe v Rossii XX vek. Tri kvadrata, Moscow

Zaytseva ME (1989) Moskva. Plan goroda [Moscow. General layout]. GUGK, Moscow

Zaytseva O, Kosareva NB (2017) Vorkug "khrusheb" [Around "khrushevki"]. Polit.ru. http://polit. ru/article/2017/04/27/khrushchevki

Zhidkin AP (2002) Territorialnie razlichiya v structure i dinamike elektoralnikh predpochteniy naseleniya Rossii [Territorial differences in the structure and dynamics of Russian population's electoral preferences] (Unpublished thesis). Lomonosov Moscow State University, Moscow

Zubarevich NV (2017) Stolichnie "vershki" i "koreshki" [Capital's "winners" and "losers"]. Vedomosti. https://www.vedomosti.ru/newspaper/articles/2017/04/26/687706-vershki-koreshki

Open Access This chapter is licensed under the terms of the Creative Commons Attribution 4.0 International License (http://creativecommons.org/licenses/by/4.0/), which permits use, sharing, adaptation, distribution and reproduction in any medium or format, as long as you give appropriate credit to the original author(s) and the source, provide a link to the Creative Commons license and indicate if changes were made.

The images or other third party material in this chapter are included in the chapter's Creative Commons license, unless indicated otherwise in a credit line to the material. If material is not included in the chapter's Creative Commons license and your intended use is not permitted by statutory regulation or exceeds the permitted use, you will need to obtain permission directly from the copyright holder.

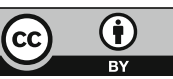

